\title{
1
}

\section{Emerging Trends in Reassessing Translation, Conflict, and Memory}

\section{Alicia Castillo Villanueva and Lucía Pintado Gutiérrez}

New Approaches on Translation, Conflict, and Memory: Narratives of the Spanish Civil War and the Dictatorship is a collection of essays that endeavours to establish a new dialogue between translation, conflict, and memory studies. Focusing on cultural representations of the Spanish Civil War and the Franco Dictatorship, it explores the significance and the effect of translation within Spain and beyond. Drawing on fictional and nonfictional texts, reports from war zones, and audiovisual productions, the contributors to this volume examine the scope of translation in transmitting the conflict and the dictatorship from a contemporary perspective. Narratives produced during and after the Civil War and the dictatorship both in Spain and abroad have led to new debates arising from the reassessment of a conflict that continues to resonate.
A. Castillo Villanueva • L. Pintado Gutiérrez ( $\)$
School of Applied Languages and Intercultural Studies, Dublin City University, Dublin, Ireland e-mail: lucia.pintado@dcu.ie
A. Castillo Villanueva
e-mail: alicia.castillovillanueva@dcu.ie
(C) The Author(s) 2019 
This book emerges from the common ground shared by our different academic interests, particularly in translation and historical memory studies, but also from an ethical commitment to justice, truth, and moral reparation for those who were erased from the official history and relegated to oblivion. Translation, conflict, and memory taken together, form an emerging field that bridges the gaps between these disciplines within Spanish studies in order to provide a solid background for further analysis and research. This book aims to give visibility to a field that still has to be studied in greater depth and which has the potential to occupy a significant position on a bigger map that depicts other narratives of conflict and translation.

During the Spanish transition to democracy, political leaders decided that, with a view to uniting the country and directing its path towards the new system of governance, some of the more problematic aspects of Spanish history of the previous five decades might be best papered over. The decision was taken not to prosecute those who had committed serious crimes; instead perpetrators were tacitly pardoned under an amnesty law passed in 1977 which was supported by the majority of the political spectrum. The legacy of the Civil War and Franco's repression was a delicate subject and to avoid the reopening of old wounds, both conservative and socialist governments proceeded with extreme caution. The collective determination to re-establish democracy by whatever means were necessary led to what would be known as the Pact of Forgetting, a curtain of silence over the past (Preston 2007: 19). Thus, the politics of memory in the transition to democracy have been described as the elimination and eradication of historical memory and a forgetting and silencing of the past (Morán 1991; Medina 2001; Labanyi 2007; Colmeiro 2011).

The Pact of Forgetting (1977) implied in turn the tacit suppression of the Republican memory and identity in both the political and public spheres (Ryan 2009). Discussion was impeded between the generations who experienced, in one way or another, this episode in Spanish history, and this has led to a debate at all levels in contemporary Spain. This reassessment has taken place in various areas of society, culture, and politics in order to recover the memory of the defeated and to complete the untold stories and the hidden history of the conflict. 
Therefore, historical memory in this context consists in recovering in the public space the memory of the violence suffered by the victims of the dictatorship marginalized in the collective story, but above all it claims justice, truth, and reparation for the victims of Francoism (Saz 2003: 56). Gálvez Biesca points to the political triumph of the conservative People's Party (PP), and specifically the government of José María Aznar (1996-2004), as the onset of the increasing socio-political sensitization and the revival of historical memory (2006: 27).

In the past few decades, the tireless efforts by different associations to give recognition to the victims of Franco's repression have made remarkable progress. The work carried out by the Association for the Recovery of Historical Memory and the passing of the controversial Historical Memory Law in 2007 under the socialist government of José Luis Rodríguez Zapatero led to the search for, and recovery of, the remains of victims of the Francoist repression. These events coincided with the commemoration in 2005 of 30 years of democracy and in 2006 with the 70th anniversary of the beginning of the war, which increased general interest and debate. Both media and literary criticism have considered this phenomenon to be a "journey back from amnesia" following the title of an article by journalist Javier Valenzuela that many critics have echoed:

It took over 25 years for democracy to confront the post-war period. Bookstores have become filled with works by historians, essayists, journalists, and novelists who give voice to the millions of Spaniards who lived a sorrowful inner exile following the Civil War. (Valenzuela 2002-our translation)

What Valenzuela describes has resulted in a growth in popular awareness of the "right to memory," so that those who were denied this right to remember might be granted recognition (Castilla del Pino 2006: 16). This has brought with it a debate that embraces the rights of the individual and the community, a discussion that grants visibility for families seeking their relatives, a public discourse in literature, cinema, and other cultural channels. According to authors such as Dulce Chacón, Santos Juliá, or Javier Cercas, this growth in awareness seems to correspond to 
an interest awakened among the new generation and the grandchildren of survivors (Valenzuela 2002). Recent Spanish fiction has focused on questions of memory in a new perspective, questions that differ from those which dominated public discourse previously in the ways in which they relate to current debates about the appropriate memorialisation of the recent past (Leggott 2015: 1). These narratives bring previously silenced Republican stories into the public domain, acknowledging the victims of nationalist repression, persecution and extra-judicial killings during the years of Civil War and the dictatorship (2015: 1).

Since the end of the dictatorship, but especially since the 1990s, there has been a rapid growth the number of cultural representations that recover the memory of the defeated. Among the titles included under the theme of "novels for the recovery of historical memory" (Ramblado Minero 2004; de Urioste 2010) are Luna de lobos (1985) by Julio Llamanzares; the trilogy comprising Historia de una maestra (1990), Mujeres de negro (1994) and La fuerza del destino (1997) by Josefina Aldecoa; Maquis (1996) by Alfons Cervera; Un calor tan cercano (1997) by Maruja Torres; El lápiz del carpintero (1998) by Manuel Rivas; Luna lunera (1999) by Rosa Regás; Un largo silencio (2000) by Ángeles Caso; Cielos de barro (2000) and La voz dormida (2002) by Dulce Chacón; Soldados de Salamina (2002) by Javier Cercas; Tu rostro mañana (2002) by Javier Marías; Las trece rosas (2003) by Jesús Ferrero; El heredero (2003) by José María Merino; El vano ayer (2004) by Isaac Rosa; Fantasmas del invierno (2004) by Luis Mateo Díez; La meitat de l'ànima (2004) by Carmen Riera; Malena es un nombre de tango (1994), Los aires difíciles (2002), El corazón helado (2007) and Inés y la alegría (2010) by Almudena Grandes; La mujer del maquis (2008) and Si a los tres años no he vuelto (2012) by Ana R. Cañil or El tiempo entre costuras (2009) by María Dueńas. Some translations include Diamond Square (trans. Peter Bush 2013) by Mercè Rodoreda, also translated in 1967 by Eda O'Sheil Sagarra as The Pigeon Girl and in the 1986 by David Rosenthal as The Time of Doves; Trapped in Spain (trans. Leandro Garza 1978) by Carlota O'Neill; The Carpenter's Pencil (trans. Jonathan Dunne 2003) by Manuel Rivas; The Soldiers of Salamis (trans. Anne McLean 2003) by Javier Cercas; The Wind from the East (trans. Sonia Soto 2007) and The Frozen Heart (trans. Frank Wynne 2010) by Almudena Grandes; 
The Sleeping Voice (trans. Nick Caistor 2006) by Dulce Chacón; and An Englishman in Madrid (trans. Nick Caistor 2013) by Eduardo Mendoza; The Time in Between (trans. Daniel Hahn 2011) by María Dueñas; or Wolf Moon (trans. Simon Deefholts and Kathryn Phillips-Miles 2017) by Julio Llamanzares.

The film industry has also echoed this trend since the transition period with works such as Los dias del pasado (1978) directed by Mario Camus, Las largas vacaciones del 36 (1976) by Jaime Camino, El corazón del bosque (1979) by Manuel Gutiérrez Aragón, jAy, Carmela! (1992) by Carlos Saura, Libertarias (1996) by Vicente Aranda, Los años bárbaros (1998) by Fernando Colomo, Silencio roto (2001) [Broken Silence] by Montxo Armendáriz, Soldados de Salamina (2003) [The Soldiers of Salamis] by David Trueba and El laberinto del fauno (2006) [Pan's Labyrinth] by Guillermo del Toro, among others. Television series such as Cuéntame cómo pasó (2001present), La chica de ayer (2009), or El tiempo entre costuras (2013) [The Time in Between] highlight the way in which, according to H. Rosi Song, "popular culture mediates the viewer's relation with the past, and how it affects the creation of both cultural and private memories" (2016: 89).

Research into this aspect of Spanish culture, which is taking place at the intersection of the young disciplines of translation, conflict, and memory studies, is still relatively scant. It has been triggered by a desire to do justice to history and the need to live in a fair society. The nexus between translation, conflict, and memory is therefore a consequence of academic, professional, and historical practices and social interests that reflect cross-lingual and cross-cultural issues in contemporary societies. The crossroads between translation, conflict, and memory is in debt to research frameworks developed in conflict and memory, translation and conflict, and translation and memory. Translation thus becomes the element that connects all three areas.

Mona Baker claims that "[d]efinitions of conflict inevitably draw on notions of power, and vice versa" (2006: 1). Tymoczko and Gentzler (2002), in their introduction, also underline the fact that power and translation are closely intertwined. As such, the intersection of translation, conflict, and memory draw on frameworks related to censorship, power, and translation among other fields. Developments in conflict and translation studies, particularly by Mona Baker and others, have drawn 
primarily on narrative theories that examine the ways in which translation and interpreting interact and their increasing visibility in war zones; Baker's work in this field in particular has developed the notion of framing in the context of activist discourse in the Middle East conflict (2006, 2007, 2010). Along similar lines, Inghilleri and Harding (2010) look at the role of translators and interpreters in violent conflicts. Tymoczko (2000) and Tymoczko and Gentzler's (2002) contributions are also essential in the exploration of translation and political engagement.

The power exercised by the state in Spain determined which cultural representations were imported into and exported out of the country through translation; exercising power in this way could become particularly contentious when references in those cultural artefacts challenged the official discourse of the Spanish conflict. This happened over a long period of time and comprised disturbing practices, from restrictive dictatorship to the prolonged silence following the Pact of Forgetting during the transition and the first years of democracy. The public outcry that has emerged in contemporary Spain can be seen as a reaction against these practices: there is now a thirst to rescue a past that was condemned to institutional, social and cultural amnesia. Tymoczko and Gentzler state the importance of studying translation "in charged political contexts" as it "illustrates the relationships between discourse and power" (2002: xix). In the Spanish context, translation was at the service of power (as we can see in Part II and III). Evidence of this can be found in reports in archives and in numerous articles and national projects. The analysis of archival sources provides an account of the restrictions that translators worked under, though it also shows the potential to act as resisting narratives stretching from one period in which there was a complete lack of freedom to another in which justice and empowerment began to be sought. The renegotiation which this transition has witnessed has enabled new discourses to emerge which have helped to reshape the narrative of the conflict and the dictatorship.

This pattern cannot be separated from the ideological forces that shape (or reshape) our societies. Translation, as Venuti argues, should follow "the same rigorous interrogation that other cultural forms and practices have recently undergone with the emergence of poststructuralism and its impact on such theoretical and political discourses as 
psychoanalysis, Marxism, and feminism" (1992: 6). This is consonant with Bassnett and Lefevere's (1990) idea that translation as rewriting reflects a certain ideology and, as such, manipulates literature to function in a given society, in a given way. This is, in fact, how Franco's regime saw translation: manipulation undertaken in the service of power; translation — or lack thereof — as a shaping force.

If, as Baker (2006) maintains, translation plays an important role in the management of conflict, then looking back over translations becomes key in the reconstruction of the past in relation to the collective imagination. In fact, if "[...] translation and interpreting are essential for circulating and resisting the narratives that create the intellectual and moral environment for violent conflict in the first place, even though the narratives in question may not directly depict conflict or war" (Baker 2006: 2 ), then we can assume that the reinterpretation of narratives that have typically been subjected to different forms of oppression will allow us to create a "sense of community with "past experiences of oppression" (Baquedano-López 2001: 344). The role that translation plays in the revision of the dominant ideologies reflected in cultural artefacts is therefore key in revisiting the Spanish conflict. In this vein, our interest lies in looking at how information travelled from or into Spain, with a special focus on the understanding and the perception of the conflict, both within and beyond the borders of the Iberian Peninsula.

Motivated by a necessity to do justice to the Republican memory, there has been a resurgence of social and cultural interest in filling this gap in the individual and collective memory, through the publication of novels and the production of numerous feature films and TV shows. Research conducted by Siobhan Brownlie (2007, 2016, 2017) marks the cornerstone in the field of translation and memory as she explores discourses on translation and conflict within a broad perspective and establishes a nexus between memory and translation. In the case of the Spanish conflict, novels, films and other types of cultural artefacts are important not only in contesting a discourse that in the past had been excluded but also in establishing an intergenerational discourse. The rewriting of history, challenging established structures of power by (re)telling stories from a new angle, emerges from a commitment to honour the memory of the victims. 
Existing works on the Spanish conflict from a contemporary perspective, together with research conducted as part of this new translation turn, is part of the emerging field of translation, conflict, and memory. Recent publications by Catalan and Spanish scholars have featured analyses of translation with reference to the position of women under Francoism (Bacardí and Godayol 2017; Godayol 2017; Godayol and Taronna 2018). Of course, this field cannot be understood without considering publications related to neighbouring areas like ethics, language, rewriting, memory, etc.

But a revision of the past through contemporary narratives that draw from memory is particularly important: "[m]emory is [...] a lived and present thing, and the traumatic past may be quite real. By the same token, an alternative positive and hopeful memory takes on great importance" (Brownlie 2016: xi). At the heart of this claim (applied to a different context) is the fact that no real reflection on the narrative(s) of the Spanish conflict and the dictatorship has yet taken place. Contemporary narratives, and their translation, challenge an established status quo, creating a forum in which historical grievances may be aired. Memory is used with a future aim: to confront the past involves questioning different contexts and actors in order to build a better future (Bickford and Sodaro 2010: 68). The past is thus interpreted through the lens of the present.

Our volume represents a commitment to current lines of research engaging with translation and conflict from a memory perspective. The contributions in this volume explore several interrelated themes through a variety of approaches, drawing on fictional and non-fictional texts, and historical and contemporary cultural artefacts related to the recovery of memory as the overarching element. In examining the translation of narratives of the Spanish conflict and the dictatorship, the main themes on which the volume focuses can be divided into four different areas, reflected in the following four sections of the book: translation as rewriting and the transmission of ideologies; translation, power and identity; translation and censorship; and translation and memory studies.

Part II focuses on the figure of Langston Hughes (1902-1967). As an African American activist poet, translator, and correspondent, Hughes dedicated much of his personal and professional life to the African American civil rights struggle. His commitment to justice led him to empathize with other struggles and his experience as a first-hand witness 
to the Spanish Civil War prompted him to draw parallels between the Spanish conflict and the African American civil rights struggle. He participated actively in the Spanish cultural sphere, perpetuating Lorca's legacy and identifying with the Republican cause. In chapter two, Patricia San José looks at ideology and explains how Hughes's domestic experience with racism and his own political views are key to him seeing a parallel between both conflicts. San Josés cultural translation approach takes its lead from the work of Walter Benjamin and Laura Izarra and sees the traveller as a witness to a historical event, who transfers his struggle to that of Spain through his own identity and vice versa. In other words, San José analyses how this prominent author translates his experiences of both conflicts through his own physical and symbolic journeys between the two cultures. Andrew Walsh also examines Hughes's personal and ideological history to explore the parallels he established between the two different conflicts, with a focus on Lorca's poetry. Langston Hughes initiates a dialogue between Lorca's demands reflected in his Gypsy Ballards, and his own demands emerging from the racial conflict in the southern states in North America. Hughes's political engagement in the struggles of oppressed minorities entails a re-reading of Lorca, whom he translates into English after visiting Spain. This gave the Spanish conflict a visibility in the USA - a country looking closely at the development of conflict-ridden Spain. Translation is explored as a tool in ideological propaganda and social empathy.

Part III examines interpreters in the Spanish conflict. The largely unexplored role of international interpreters during the Spanish Civil War is uncovered, revealing the challenges they faced when trying to establish fluent communication on the frontline. Marcos Rodríguez Espinosa looks at the International Brigades and their role as communicators. The 35,000 volunteers from numerous backgrounds comprised a radically diverse group, not only in terms of their cultural backgrounds, but also with regard to their languages and ideologies. The author brings together work from a variety of disciplines to depict how the international brigades communicated. Rodríguez Espinosa addresses in this fashion issues regarding communication, ideology, and interpreting in the Spanish conflict. The frameworks that he applies follow those outlined by Salama-Carr (2007), Baker (2010), Inghilleri and 
Harding (2010), and Footitt (2012) among others. Matters relating to interpreting in conflict among multilingual battalions and the issues that arise have hardly been addressed in accounts of the Spanish Civil War. This chapter therefore offers an insightful perspective on the ordeal, and the division and hostility encountered by translators and interpreters in the Republican war zone throughout the conflict.

Part IV offers insightful analyses of the regime's modus operandi regarding censorship of foreign (specifically North American) texts and productions that challenged the ideology imposed by Franco's dictatorship. The three chapters show how censorship was one of the most powerful and effective systems of control preventing subversive ideologies (such as feminism or communism) that deviated from those established by the regime. Based on the censorship records kept at the Archivo General de la Administración (General Archives of the Administration) in Alcalá de Henares, these authors cast new light on how the manipulation of foreign literature by the censor contributed to strengthening the regime's idea of a Spanish identity based on the ideology of National Catholicism. Pilar Godayol focuses on the controversial figure of the novelist and critic Mary McCarthy (1912-1989) whose works, translated into Spanish and Catalan under Franco, were clearly considered by the regime to be 'dangerous' due to the atheist, feminist and communist tendencies of the writer. McCarthy's references to free love, adultery, or birth control were considered immoral and harmful for women and strongly contravened the National-Catholic code. Using a methodology that takes its lead from Jeremy Munday's notion of "microhistory" in translation studies (2014), this chapter investigates the censors' files on the Barcelona publishers who wished to publish translations of McCarthy's novels in the 1960s and 1970s. Godayol focuses on archival sources relating to three novels translated into Spanish during this period (The Group, A Charmed Life, and Birds of America), drawing on the contradictions and misunderstandings recorded in the censor's reports at the General Archive of the Administration.

Literature for children was also a target for the regime in their efforts to indoctrinate the young and, in so doing, secure the perpetuation of National-Catholic family values. Focusing on Mark Twain's novel The Adventures of Huckleberry Finn (1885), Julia Lin Thompson explores 
how texts produced for children were deemed an effective tool for ideological homogenisation. While controversies concerning the reception of the novel in the source culture do not necessarily guarantee its censorship in the target culture, Twain's satirical treatment of religion and his contemptuous attitudes towards authority and social norms, as expressed through the voice of his protagonist Huckleberry Finn, did clash with ideas of what was deemed good children's literature under Francoism, and thus the translations of this novel were subject to censorship. By examining translations of this novel, Thompson analyses how a knowledge of what it withheld from children is of equal importance to a knowledge of what it attempted to inculcate.

Rosa Bautista's chapter focuses on the translation of Adventures of a Young Man by John Dos Passos, in which the hero, Glenn Spotswood, is a fervent anti-fascist who, after taking part in radical workers' movements in the U.S., enlists to fight Franco in Loyalist Spain. Bautista presents a case study of the power exercised by Franco's censors over the Spanish cultural polysystem (Even-Zohar 1990) and, more specifically, over the translation of foreign works of literature dealing with the Spanish Civil War. Based on scholars from the so-called Manipulation School Bautista's analysis of the censorship files, along with the identification of manipulated fragments in the translation, indicate that Franco's administration used banned foreign works such as Dos Passos's as propaganda tools.

The closing section is dedicated to the intersection of translation, conflict and memory, focusing on questions that relate to current debates about ways of memorializing the past. Contributions explore how cultural productions are built from memory and postmemory and the role of translation in framing such memories of the conflict and the dictatorship in other societies. The chapters in this section respond to a current social demand to reestablish the memory of the defeated through different genres, including a TV series, a novel, and poetry. Kyra Kiertrys examines the Spanish television series El tiempo entre costuras in light of the evolving social, cultural, and political discourses in twenty first century Spain around memories of the Civil War. She also explores the impact of Netflix's expanding international programming on perceptions of Spanish history outside Spain. 
Kiertys's approach relies on a fourfold understanding of translation as: (1) intra-cultural translation, or the transmission of collective memory from one generation to another; (2) adaptation from one medium to another-novel to screen; (3) inter-cultural translation, or the transmission of cultural memory from one culture to another-Spanish to U.S. American; and (4) inter-lingual translation-here, Spanish to English. Through a humanistic exploration of the idiosyncrasies of a high-profile contemporary Spanish television series, this chapter shows that El tiempo entre costuras moves the collective memories around Spain's painful past away from trauma, forgetting, and the recovery of the forgotten, in order to create a new memory that looks towards the future. Inês Espada Vieira examines how silenced memory is transmitted and how the "dialogic forgetting" (Assman 2010) does not necessarily imply forgetting. In this chapter, memory is seen as movement, as traffic and motion. In Los girasoles ciegos she explores the concept of transnational memory (Brownlie 2017) as memory that crosses geographical and cultural borders and, in this case, migrates into Portuguese culture. Following Erll's (2011) proposal of five dimensions of movement-carriers, media, contents, practices and forms - the author argues that the memory of the Spanish Civil War and the dictatorship moves within Portuguese culture through carriers as content and also as form. The last chapter by Pilar Cáceres engages with Derrida's idea of hauntology and his views on translation within the field of memory studies. Using this framework the author analyses The Hair of the Shoah, the only Jewish Holocaust-related poem in Spanish poetry of the twentieth century. Composed as a book-length poem by Félix Grande, this work is unique both in its theme and its structure. The chapter discusses and frames Grande's work within the context of the poet's traumatic experience of the catastrophe. Cáceres explores how Grande's poetic mechanisms to deal with historical loss are akin to the ideas underpinned in Derrida's concepts of untranslatability and hauntology. The author analyses how Grande demonstrates that all deep traumas constitute untranslatable experiences that paradoxically call for a translation similar to Grande's exploration of Jewish suffering in the poem. 
Revisiting the Spanish conflict and the recovery of historical memory within contemporary Spain is a recent phenomenon that has been represented not only in literature, cinema, and other cultural forms, but it has also generated social debate in the media, blogs and other channels. Translation becomes key in the revision of ideas about the conflict and the dictatorship and is a new tool to recover the memory of the defeated in a new perspective that connects with current debates on the subject. This collection of essays opens a critical discussion on prevailing views on this topic by examining the (inter)connection between artefacts and the circulation of resisting narratives. Engaging in this intergenerational and intercultural exploration will encourage global dialogue to continue gaining pace. This volume responds to a social demand that is part of a general need across different countries, to recover and repair traumatic experiences throughout the twentieth century, including the Holocaust and France during the 1970s, and more recently in other countries in Eastern Europe, Latin America, or South Africa. Translation is vital to this global recovery of memory.

\section{References}

\section{Primary Sources}

Novels

Aldecoa, Josefina. 1990. Historia de una maestra. Barcelona: Anagrama. . 1994. Mujeres de negro. Barcelona: Anagrama.

- 1997. La fuerza del destino. Barcelona: Anagrama.

Cañil, Ana R. 2008. La mujer del maquis. Barcelona: S.L.U. Espasa Libros. 2012. Si a los tres años no he vuelto. Barcelona: S.L.U. Espasa Libros.

Caso, Ángeles. 2000. Un largo silencio. Barcelona: Booklet, Planeta.

Cercas, Javier. 2002. Soldados de Salamina. Barcelona: Tusquets.

Cervera, Alfons. 1996. Maquis. Barcelona: Montesinos.

Chacón, Dulce. 2000. Cielos de barro. Barcelona: Planeta. . 2002. La voz dormida. Madrid: Alfaguara.

Dueñas, María. 2009. El tiempo entre costuras. Barcelona: Temas de Hoy. 
Ferrero, Jesús. 2003. Las trece rosas. Madrid: Siruela.

Grandes, Almudena. 1994. Malena es un nombre de tango. Barcelona: Tusquets.

—. 2002. Los aires difíciles. Barcelona: Tusquets.

- 2007. El corazón helado. Barcelona: Tusquets.

- 2010. Inés y la alegría. Barcelona: Tusquets.

Llamanzares, Julio. 1985. Luna de lobos. Barcelona: Seix Barral.

Marías, Javier. 2002. Tu rostro mañana. Madrid: Alfaguara.

Mateo Díez, Luis. 2004. Fantasmas del invierno. Madrid: Alfaguara.

Merino, José María. 2003. El heredero. Madrid: Alfaguara.

Regás, Rosa. 1999. Luna lunera. Barcelona: Debolsillo, Plaza y Janés.

Riera, Carmen. 2004. La meitat de l'ànima. Barcelona: Edicions Proa.

Rivas, Manuel. 1998. El lápiz del carpintero. Madrid: De Bolsillo, Punto de Lectura.

Rosa, Isaac. 2004. El vano ayer. Barcelona: Seix Barral.

Torres, Maruja. 1997. Un calor tan cercano. Madrid: Alfaguara.

\section{Translations}

Cercas, Javier. 2003. The Soldiers of Salamis, trans. Anne McLean. London: Bloomsbury.

Chacón, Dulce. 2006. The Sleeping Voice, trans. Nick Caistor. London: Harvill Secker.

Dueñas, María. 2011. The Time in Between, trans. Daniel Hahn. New York: Atria Books.

Grandes, Almudena. 2007. The Wind from the East, trans. Sonia Soto. New York: Seven Stories Press.

- 2010. The Frozen Heart, trans. Frank Wynne. London: Weidenfeld \& Nicolson.

Llamanzares, Julio. 2017. Wolf Moon, trans. Simon Deefholts and Kathryn Phillips-Miles. London: Peter Owen Publishers.

Mendoza, Eduardo. 2013. An Englishman in Madrid, trans. Nick Caistor. London: MacLehose Press.

O'Neill, Carlotta. 1978. Trapped in Spain, trans. Leandro Garza. Toronto: Dumont Press. 
Rivas, Manuel. 2003. The Carpenter's Pencil, trans. Jonathan Dunne. London: Vintage.

Rodoreda, Mercè. 1967. The Pigeon Girl, trans. Eda O'Shiel. London: André Deutsch.

- 1986. The Time of the Doves, trans. David Rosenthal. Saint Paul, MN: Graywolf Press.

—. 2013. Diamond Square, trans. Peter Bush. London: Virago.

\section{Films}

Aranda, Vicente. 1996. Libertarias. Spain: Sogetel and Lolafilm.

Armendáriz, Montxo. 2001. Silencio Roto. Spain: Oria Films.

Camino, Jaime. 1976. Las largas vacaciones del 36. Spain: José Frade Producciones Cinematográficas S.A.

Camus, Mario. 1978. Los días del pasado. Spain: Impala.

Colomo, Fernando. 1998. Los años bárbaros. Spain-France: Sogetel, Fernando Colomo P.C., Mainstream, Warner Sogefilms, Canal+España, Canal + Francia.

Gutiérrez Aragón, Manuel. 1979. El corazón del bosque. Spain: Arándano.

Saura, Carlos. 1992. ¡Ay, Carmela! Spain-Italy: Iberoamericana Films, Ellepi, RTVE.

Toro, Guillermo del. 2006. El laberinto del fauno. Spain-Mexico-United States: Estudios Picasso, Tequila Gang, Tele5, Sententia Entertainment.

Trueba, David. 2003. Soldados de Salamina. Spain: Lolafilms, Fernando Trueba Producciones Cinematográficas, Televisión Española (TVE).

\section{TV Series}

Bernardeau, Miguel Ángel. 2001-present. Cuéntame cómo pasó. Spain: Grupo Ganga, Televisión Española (TVE).

Mercero, Ignacio, Álvaro Ron, Alfonso Arandia, and José Ramos Paíno. 2009. La chica de ayer. Spain: Antena 3 Televisión.

Mercero, Ignacio, Ińaki Peñafiel, and Norberto López Amado. 2013. El tiempo entre costuras. Spain: Boomerang TV, Antena 3 Televisión. 


\section{Secondary Sources}

Assman, Aleida. 2010. From Collective Violence to a Common Future: Four Models for Dealing with a Traumatic Past. In Conflict, Memory Transfers and the Reshaping of Europe, ed. Helena Gonçalves da Silva, Adriana Alves de Paula Martins, Filomena Viana Guarda, and José Miguel Sardica, 8-23. Newcastle-upon-Tyne: Cambridge Scholars Publishing.

Bacardí, Montserrat, and Pilar Godayol. 2017. Traducció i franquisme. Lleida: Punctum.

Baker, Mona. 2006. Translation and Conflict: A Narrative Account. London: Routledge.

- 2007. Reframing Conflict in Translation. Social Semiotics 17 (2): $151-169$.

- 2010. Interpreters and Translators in the War Zone: Narrated and Narrators. The Translator 16 (2): 197-222.

Baquedano López, Patricia. 2001. Creating Social Identities Through Doctrina Narratives. In Linguistic Anthropology: A Reader, ed. Alessandro Duranti, 343-358. Malden, MA: Blackwell.

Bassnett, Susan, and André Lefevere (eds.). 1990. Translation, History and Culture. London: Printer Publishers.

Benjamin, Walter. 1969. The Task of the Translator. In Illuminations: Essays and Reflections, trans. Harry Zohn, 69-82. New York: Schocken Books. Bickford, Lewis, and Amy Sodaro. 2010. Remembering Yesterday to Protect Tomorrow: The Internationalization of a New Commemorative Paradigm. In Memory and the Future: Transnational Politics, Ethics and Society, ed. Yifat Gutman, Adam D. Brown, and Amy Sodaro, 66-86. Houndmills: Palgrave Macmillan.

Brownlie, Siobhan. 2007. Situating Discourse on Translation and Conflict. Social Semiotics 17 (2): 135-150.

- 2016. Mapping Memory in Translation. Houndmills, Basingstoke: Palgrave Macmillan.

- 2017. Institutional Memory and Translating at the DGT. The Translator 23 (1): 1-16.

Castilla del Pino, Carlos. 2006. La forma moral de la memoria. A manera de prólogo. In El derecho a la memoria, ed. F. Gómez Isa, 15-22. Zarautz: Alberdania.

Colmeiro, José. 2005. Memoria histórica e identidad cultural: de la postguerra a la postmodernidad. Barcelona: Rubí. 
- 2011. ¿Una nación de fantasmas? Apariciones, memoria histórica y olvido en la España posfranquista. 452 Revista electrónica de literatura y literatura comparada 4: 17-34.

Derrida, Jacques. 1994. Spectres of Marx. New Left Review 205: 31.

Erll, Astrid. 2011. Travelling Memory. Parallax 17 (4): 4-18.

Even-Zohar, Itamar (ed.). 1990. Polysystem Studies. Special Issue of Poetics Today 11: 1.

Footitt, Hilary. 2012. Introduction: Languages and the Military: Alliances Occupation and Peace Building. In Languages and the Military: Alliances Occupation and Peace Building, ed. Hilary Footitt and Michael Kelly, 1-11. Houndmills: Palgrave Macmillan.

Gálvez Biesca, Sergio. 2006. El proceso de la recuperación de la 'memoria histórica’ en España: Una aproximación a los movimientos sociales por la memoria. International Journal of Iberian Studies 1: 25-51.

Godayol, Pilar. 2017. Tres escritoras censuradas: Simone de Beauvoir, Betty Friedan y Mary McCarthy. Comares: Granada.

Godayol, Pilar, and Annarita Taronna (eds.). 2018. Foreign Women Authors Under Fascism and Francoism: Gender, Translation and Censorship. Newcastle: Cambridge Scholars Publishing.

Holmes, James S. 1988. The Name and Nature of Translation Studies. In Translated! Papers on Literary Translation and Translation Studies, ed. James S. Holmes, 66-80. Amsterdam: Rodopi.

Inghilleri, Moira, and Sue Ann Harding. 2010. Translating Violent Conflict. The Translator 16 (2): 165-173.

Izarra, Laura P.Z. 2004. Locations and Identities in Irish Diasporic Narratives. Hungarian Journal of English and American Studies 10 (1-2): 341-352.

Labanyi, Jo. 2007. Memory and Modernity in Democratic Spain: The Difficulty of Coming to Terms with the Spanish Civil War. Poetics Today 28 (1): 89-116.

Leggott, Sarah. 2015. Memory, War and Dictatorship in Recent Spanish Fiction by Women. Lewisburg: Bucknell University Press.

Leggott, Sarah, and Ross Woods (eds.). 2014. Memory and Trauma in the Postwar Spanish Novel. Lewisburg: Bucknell University Press.

Medina Domínguez, Alberto. 2001. Exorcismos de la memoria: políticas y poéticas en la España de la Transición. Madrid: Ediciones Libertarias.

Mistral, Silvia, and José F. Colmeiro. 2009. Éxodo: Diario de una refugiada española. Barcelona: Icaria. 
Morán, Gregorio. 1991. El precio de la transición. Barcelona: Planeta.

Munday, Jeremy. 2014. Using Sources to Produce a Microhistory of Translation and Translators: Theoretical and Methodological Concerns. The Translator 20 (1): 64-80.

Preston, Paul. 2007. A Guerra Civil Setenta Anos Depois. In Guerra Civil de Espanha: cruzando fronteiras, ed. Jorge Farenza Lourenço and Inês Espada Vieira. Lisbon: Universidade Católica Editora.

Ramblado Minero, Cinta. 2004-2005. Novelas para la recuperación de la memoria histórica: Josefina Aldecoa, Ángeles Caso y Dulce Chacón. Letras Peninsulares 17 (2-3): 361-380.

Ryan, Lorraine. 2009. For Whom the Dominant Memory Tolls: The Suppression and Re-emergence of Republican Memory and Identity in Spain. In The Essence and the Margin: National Identities and Collective Memories in Contemporary European Memory Culture, ed. Laura Rorato and Anna Saunders, 119-135. Amsterdam: Rodopi.

Salama-Carr, Myriam (ed.). 2007. Translating and Interpreting Conflict. Amsterdam: Rodopi.

Saz, Ismael. 2003. Franquismo, el pasado que aún no puede pasar. Pasajes: Revista de pensamiento contemporáneo 11: 51-59.

Song, H. Rosi. 2016. Lost in Transition: Constructing Memory in Contemporary Spain. Liverpool: Liverpool University Press.

Treglown, Jeremy. 2014. Franco's Crypt: Spanish Culture and Memory Since 1936. New York: Farrar, Straus and Giroux.

Toury, Gideon. 1978. The Nature and Role of Norms in Literary Translation. In The Translation Studies Reader, ed. Lawrence Venuti, 205-218. New York and London: Routledge.

- 1995. Descriptive Translation Studies and Beyond. Amsterdam and Philadelphia: John Benjamins.

Tymoczko, Maria. 2000. Translation and Political Engagement. The Translator $6(1): 23-47$.

Tymoczko, Maria, and Edwin Gentzler (eds.). 2002. Translation and Power. Amherst: University of Massachusetts Press.

Urioste, Carmen de. 2010. Guerra Civil y modernidad: El caso de El corazón helado de Almudena Grandes. Revista Hispánica Moderna 63 (1): 69-84.

Valenzuela, Javier. 2002. El despertar tras la amnesia. Babelia, El Pais Digital, 2 November.

Venuti, Lawrence. 1992. Rethinking Translation: Discourse, Subjectivity, Ideology. London: Routledge. 